\title{
Chrysostom's reception of Luke 19:8b (the declaration of Zacchaeus)
}

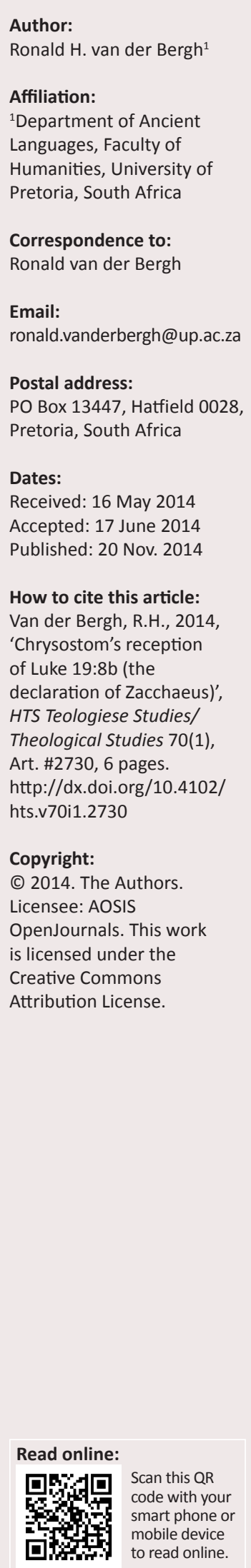

This article investigates the reception of Luke 19:8b in the works of Chrysostom. The ambiguous nature of Luke 19:8b in its Lukan context provides a glimpse into Chrysostom's thoughts on this passage. In asking the question of how Chrysostom viewed Zacchaeus's salvation to be effected (cf. the direct speech of Jesus in Luke 19:9-10), the article demonstrates that Chrysostom's consistent concern, wherever reference to Luke 19:8b is made, is with adequate compensation to people who have been wronged. The article also points out how Chrysostom did not shy away from making slight changes to the biblical narrative to convey this message.

\section{Introduction}

Ambiguities in biblical text frequently provide an entry point into the theology and interpretative framework of early Christian authors. To clear up these ambiguities, authors had to make interpretative choices, thereby baring their own presuppositions and predilections. Luke 19:8b is such an ambiguous text. It reads: 'Look, half of my belongings, Lord, I give to the poor, and if I

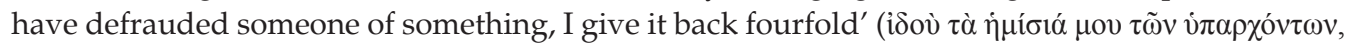

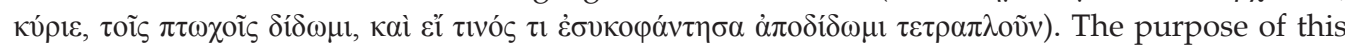
article is to investigate how a single author, Chrysostom, received and applied Luke 19:8b in his writings. The investigation highlights general themes that were regularly connected with Chrysostom's use of Luke 19:8b. At the same time, the investigation also demonstrates the variety of uses that an ancient author could find for a single verse.

The context of Luke 19:8b presents at least two ambiguities. Firstly, Luke 19:8b is ambiguous regarding how much Zacchaeus promises to repay. ${ }^{1}$ It could be implied that Zacchaeus would give away all of his possessions (cf. Jesus' demand of the rich man in Luke 18:18-23) - half of them as promised explicitly and the other half in repayment to the people he wronged. Secondly, the exact link between Zacchaeus's declaration concerning his possessions and Jesus' pronouncement of 'salvation' (Lk 19:9) is not easy to determine. ${ }^{2}$ In Luke 19:9-10, Jesus responds to Zacchaeus statement with the enigmatic:

Salvation has come to this house today, for this man too is a son of Abraham. For the Son of Man came to seek and save that which is lost.

Is Jesus' statement a direct response to Zacchaeus's promise of almsgiving and restitution, a reference to salvation based on Zacchaeus's ethnicity, or a reference to salvation based on Jesus' own active seeking and saving of Zacchaeus? In the analysis of Chrysostom's reception of Luke 19:8b below, special attention is paid to two questions: (1) how much did Chrysostom think Zacchaeus promised to give away; and (2) how, according to Chrysostom, was Zacchaeus's 'salvation' effected?

In the following text, I analyse the context of each reference to Luke 19:8b in the works of Chrysostom individually. I then draw some general conclusions about what Chrysostom's reception of Luke 19:8b betrays about his understanding of this verse.

\footnotetext{
1.As Tannehill (1986:123-124) notes, whether Zacchaeus gave up all of his possessions or not is probably not a main concern for the author of Luke. However, even Tannehill (1994:203) succumbs to the temptation of clearing up this ambiguity, stating that 'it is a mistake to assume that Zacchaeus is trying to strike a bargain, offering less than Jesus demanded of the rich man in 18:22.' Perhaps the author of Luke deliberately left this question open to interpretation as a narrative device (cf. Sternberg 1985:186-229).

2.The declaration by Zacchaeus in Luke 19:8b has been the focus of considerable debate (cf. Rohrbaugh 2007:279-280). On the one hand, there are those who view the pericope, Luke 19:1-10, as a narrative of vindication (e.g. Ravens 1991; White 1979). For this group,

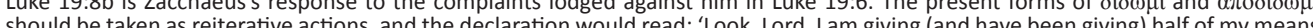
should be tak to the poor, and if (unwitting) deprive someon . Tannehill 1994). For this group, Luke 19:8b is a sign of Zacchaeus's conversion. The present forms of $\delta i \delta \omega \mu l$ and $\dot{\alpha} \pi$ o $\delta i \delta \omega \mu \mathrm{s}$ should be taken as ingressive or a mark of a future action, and the declaration would read: 'Look, Lord, I will give half of my means to the poor and if I defrauded someone of something, I will repay it fourfold.' Chrysostom's use of the future tense for Zacchaeus's declaration

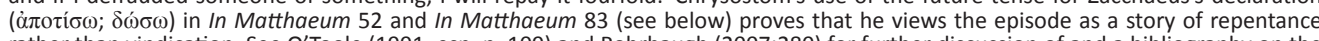
rather than vindication. See O'Toole (1991, esp. p. 109) and Rohrbaugh (2007:280) for further discussion of and a bibliography on the literary form of the pericope.
} 


\section{Chrysostom's reception of Luke 19:8b}

\section{De beato Philogonio}

The first reference to Luke 19:8b that I address is in Chrysostom's homily De beato Philogonio ${ }^{4}$ In the relevant section of this work, Chrysostom explains that no one can use 'shame' or a heavy conscience as an excuse for not giving alms. He points to the Ninevites in the biblical account of Jonah as an example of how shame and sin can be radically turned around in a very short time. Next, he gives the woman who anointed Jesus' feet with ointment as an example of how even previously shameful things can be used for good, 'because through that with which she bewitched men,

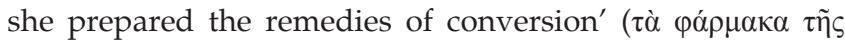
$\mu \varepsilon \tau \alpha$ voías - PG 48:754). He names three instruments that this woman used previously for sin, and explains how they were later used for good:

Through that which she raised the expectations of the unchaste (i.e. her eyes), she cried; through that with which she tripped many into sin (i.e. her hair), she wiped the feet of Christ; through the ointment, with which she enticed many, she anointed his feet. ${ }^{5}$ (De beato Philogonio 4)

Chrysostom then encourages his readers ${ }^{6}$ to use the same things that provoked God to make God favourable again. If God was provoked by the theft of possessions (

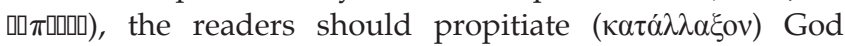
through these same possessions 'by both giving back the stolen goods to those wronged, and giving them even more things (literally: "other things in addition").' The readers should say with Zacchaeus (

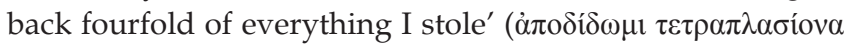

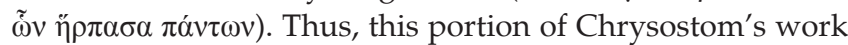
is actually not primarily concerned with almsgiving, but rather the possibility of restitution through almsgiving.

Chrysostom does not conceive here of the action of repayment as a quid pro quo, as if the exact things stolen should be returned. Rather, the conduct established by a person's decision to make restitution is sufficient, as the following quote in the same section demonstrates:

These things [i.e. the actions needed to propitiate God] do not require

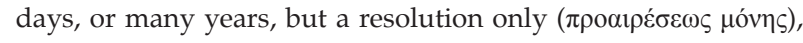
and they are set aright in one day. Stay away from wickedness,

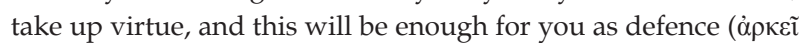

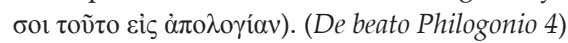

3.An additional, indirect reference to Luke 19:8b (or perhaps Ex 22:1) in the works of Chrysostom can be found in his series of homilies on Ephesians (In epistulam ad Ephesios). The text he is concerned with in his 18th homily, which concerns Ephesians 5:56, centres on the description of a 'covetous person, which is an

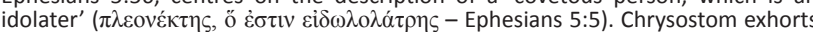
his listeners to ' $t$ t hink about all that you have robbed, everything that you have

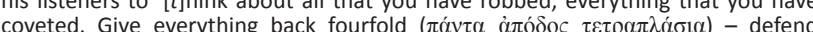

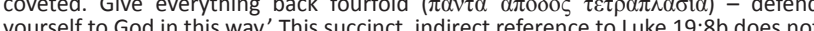
yourself to God in this way.' This succinct, indirect reference to Luke 19:8b does not answer the questions asked in the present article and has consequently not been
included in my discussion.

4.De beato Philogonio is homily 6 of the Contra Anomoeos. The text can be found in PG 48:747-756; the reference to Luke 19:8b is on page 754 .

5.Unless otherwise indicated, translations in this article are my own.

6.All of Chrysostom's works treated in this paper are homilies and were once delivered orally. By using the term 'readers' instead of 'audience', I do not want to deny the original function of these homilies, but merely seek to emphasise their written nature as they have come down to us.
In De beato Philogonio 4, Chrysostom does not necessarily link Zacchaeus's 'salvation' with his declaration, but his declaration definitely serves to propitiate God. We again find this theme of propitiation in other texts of Chrysostom (see the discussion below).

\section{De Lazaro}

In the second series of homilies on Luke 16:19-31 (the narrative of Lazarus and the rich man), Chrysostom dwells at length on the possibility that the rich man could have prevented going to 'Gehenna' ( $\gamma \varepsilon$ ' $v v \alpha)$ had he been warned and reacted on this warning. ${ }^{7}$ Chrysostom warns his readers that they are confronted with the same choice as the rich man and should therefore always contemplate their ultimate destination. He quotes two verses from Scripture to illustrate this point: Sirach 7:36 and Proverbs 24:27. Sirach 7:36 reads (in the form that Chrysostom cites): 'In all your reckonings,

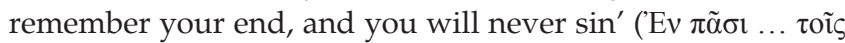

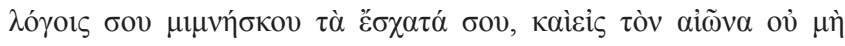

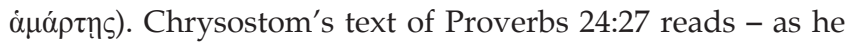
patently understands it: 'Ready your works for [your] death,

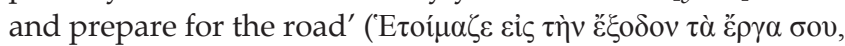

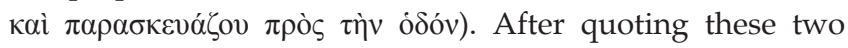
verses, Chrysostom states:

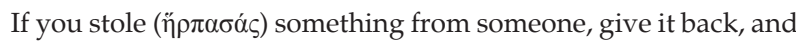
say with Zacchaeus: 'I give back fourfold what I stole' ( $\Delta$ í $\delta \omega \mu$

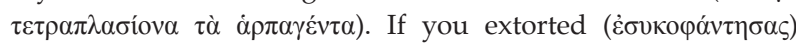
something from someone, if you became someone's enemy, be

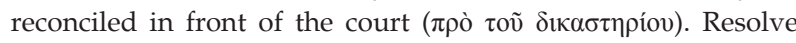
everything there, so that you might see the bench ( $\tau$ ò $\beta \tilde{\eta} \mu \alpha)$ without trouble (cf. Matthew 5:25-26). (De Lazaro 2.3)

As with Chrysostom's reference to Luke 19:8b in De beato Philogonio, there is a close correlation between Zacchaeus's declaration and his 'salvation' in De Lazaro 2.3, even though he does not state it explicitly. Chrysostom does not forthrightly state that Zacchaeus's declaration and subsequent actions saved him, but the preceding discussion implies that Zacchaeus's actions, just like the actions of Chrysostom's readers, had some kind of implication for where he spent eternity. Chrysostom's concern in De Lazaro 2.3 is mainly with restitution, and no mention is made of almsgiving in this text.

\section{In Matthaeum}

In a homily on Matthew 9:9 (the calling of Matthew - In Matthaeum 30), ${ }^{8}$ Chrysostom explains that Jesus' willingness to share a place at Matthew's table despite criticism from others lead to Matthew's conversion. Chrysostom concludes from this event that Jesus did not shrink from applying any type of remedy in trying to better people (cf. PG 57:363-364). In fact, he compares the unjustly gained wealth that Matthew serves at his table with a disease with which a doctor (Jesus) is not afraid to come into contact in order to heal a patient. He refers to the 7.The Greek text of this second series of homilies on Lazarus, the De Lazaro, can be
found in PG 48:963-1054. The reference to Luke 19:8b, which occurs in De Lazaro 2.3 , is on page 985 .

8.The Greek text of In Matthaeum 30 is in PG 57:361-369. The reference to Luke 19:8b is on page 364 . 
story of Zacchaeus, as analogous to the story of Matthew, to prove his point:

And so that you can learn that this great thing was caused by his fellowship at the table [i.e. the fellowship of Jesus and Matthew], listen to what Zacchaeus, another tax-gatherer, says; for when he heard Christ saying 'Today, I must stay in your house', he was overwhelmed by joy and said: 'Half of my belongings I give to the poor, and if I wronged someone, I give back fourfold (Tà

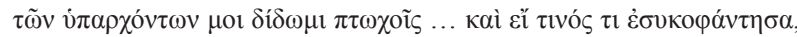
$\dot{\alpha} \pi \circ \delta \delta \delta \omega \mu \iota \tau \tau \varepsilon \tau \alpha \pi \lambda \circ o \tilde{v}) . '$ And Jesus said to him: 'Today, salvation has come to this house'. (In Matthaeum 30.2)

Here, Chrysostom views the Zacchaeus narrative as a conversion story, one in which Jesus' readiness to associate with less than savoury characters is the cause of conversion. Chrysostom retains Luke 19:8b's ambiguity regarding the quantity of Zacchaeus's possessions, and follows the sequence of Luke 19:1-10. By breaking off the quotation before

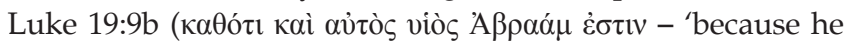
too is a son of Abraham'), Chrysostom portrays Zacchaeus's salvation as directly connected with his declaration. However, seen in the larger context of the argument, Chrysostom is perhaps more concerned to show that Jesus' willingness to associate with Zacchaeus leads to his conversion - that is that Jesus came to seek and save Zacchaeus - and that the declaration is a response to this willingness.

Chrysostom again makes use of Luke 19:8b in In Mattheum $52 .{ }^{9}$ In the section where Chrysostom refers to Luke 19:8b, he argues that providing recompense for an act of wronging is never complete when only the exact amount is returned:

For if you defrauded (someone of) an obol, you ought not to give an obol in alms, so that the wound of the extortion is removed, but [rather] a talent. (In Mattheum 52)

Chrysostom further argues that a thief ( $\kappa \lambda \dot{\varepsilon} \pi \tau \eta \varsigma$ - i.e. someone who steals without the use of violence) who is caught should return what he stole fourfold, but someone who robs (ó $\dot{\alpha} \rho \pi \alpha ́ \zeta \omega v$ - i.e. someone who steals by using violence) is worse: such a person should give back ten times and even

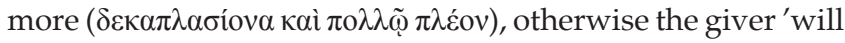

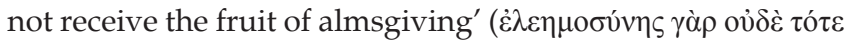

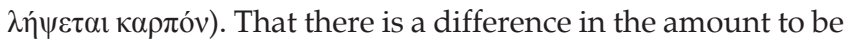
repaid by people committing different sins demonstrates that Chrysostom saw a correlation between the nature of the sin and the compensation. This is also evident in the very next sentence, as Chrysostom continues:

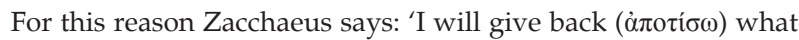
I have extorted fourfold, and half of my possessions I will give ( $\delta \omega \sigma \sigma \omega)$ to the poor.' But if by law he must give fourfold, how much more by grace: if a thief (must repay fourfold), how much more a robber. For with the loss there also (comes) great insolence, so that if you could give hundredfold, you have not yet given everything. (In Matthaeum 52)

To construct his argument, Chrysostom has to switch around two elements in Luke 19:8b: whereas Luke 19:8b has almsgiving first, followed by compensation, Chrysostom makes Zacchaeus declare compensation first and then

9.The Greek text of In Matthaeum 52 can be found in PG 58:517-526. The reference to Luke $19: 8 \mathrm{~b}$ is on page 525 almsgiving. Chrysostom's reshuffling of Luke 19:8b stems from his strong advocacy for compensation for the person wronged. If the compensation is not made to the one wronged but through giving alms to others, Chrysostom argues, one would still be in the wrong - in fact, 'what hope

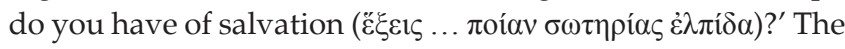
point that Chrysostom therefore wants to emphasise is not how much Zacchaeus gave away, but the fact that he made more restitution than was required of him by the law.

In a homily on Matthew 26:36-38 (the start of the praying scene in the garden of Gethsemane - In Matthaeum 83), ${ }^{10}$ Chrysostom digresses into a discussion on the folly of being wealthy and not taking heed of that which is really important. Taking up the metaphor of a house, Chrysostom contends that the poor man's dwelling, in contrast to the rich man's, is in fact 'most adorned'. ${ }^{11}$

And so that you can learn that this is the best adorning of a house, enter the house of Zacchaeus. Look how he adorned it when Christ was about to enter - for he did not run to his neighbours to ask for curtains, chairs and ivory seats or get the Laconian drapery from his treasury. Instead, he adorned [his house] it with an adornment suitable to Christ. What was this [adornment]? 'Half of my belongings I will give away ( $\delta \omega \sigma \omega)$ to the poor,' he said, 'and whatever I robbed ( fourfold.' Let us also adorn our houses like this, so that Christ may enter into us too. (In Matthaeum 83)

For rhetorical effect, Chrysostom inverts the course of events as found in Luke 19:1-10 by making Jesus enter Zacchaeus's house only after the latter's declaration (cf. the order in Luke 19:7-8). This is done because Chrysostom wants to argue that, if his readers act like Zacchaeus, their 'house' will be fitting for Jesus and he will consequently enter. The opposite would apply if their 'house' is not in order - the devil ( Chrysostom does not explicitly use the term 'salvation' here, it is probably what he envisions. For Chrysostom, Zacchaeus's 'salvation' appears to be contingent on his declaration - Jesus entered because Zacchaeus adorned his house correctly. Chrysostom takes care, however, to state that this 'unseemliness' is 'not said about those who are rich for a useful purpose, but of the grasping, and the covetous' (NPNF $10: 482)$.

\section{In epistulam primam ad Corinthios}

In homily 15 of a series of homilies on first Corinthians (In epistulam primam ad Corinthios), ${ }^{12}$ Chrysostom makes another reference to Luke 19:8b. He likens the 'old leaven' ( $\pi \alpha \lambda \alpha$ iò $v$ $\zeta$ ú $\mu \eta v)$ of 1 Corinthians 5:6-8, which should be thrown out, to 'covetousness' $(\pi \lambda \varepsilon 0 v \varepsilon \xi i \alpha)$. The priests should remove

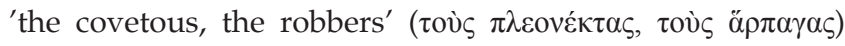
from the borders of the church, but they do not. Chrysostom

10.In Matthaeum 83's Greek text can be found in PG 58:745-752. The reference to Luke $19: 8 \mathrm{~b}$ is on page 750 .

11.In the foregoing passage, Chrysostom likened the rich man's house to a theatre that distorts reality. A similar theme runs throughout Chrysostom's De Lazaro (for which see Cardman 2008)

12.In epistulam primam ad Corinthios 15 is on 1 Corinthians 5:1-2. The Greek text of this homily can be found in PG 61:121-130. The reference to Luke 19:8b is on page 127. 
argues that being covetous even applies to someone who has inherited goods acquired through unjust acts, or keeps a stolen thing knowingly. For this reason, Chrysostom argues:

If then you know the people who were wronged, give back [the stolen property], and do exactly what Zacchaeus did, [by giving] much in addition ( $\mu \varepsilon \tau \grave{\alpha} \pi \mathrm{\alpha} \lambda \lambda \tilde{\eta} \varsigma \tau \tilde{\eta} \varsigma \pi \rho \circ \sigma \theta \eta \dot{\kappa} \kappa \varsigma)$. But if you don't know them, I offer you even another way, and I don't exclude you from being healed: distribute all of these things to those in need,

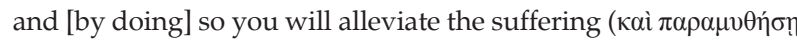

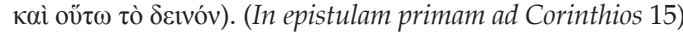

In the following text, Chrysostom connects this piece of advice with the eschatological judgement, where both parties will be 'naked' - except that the guilty parties will have charges brought against them. The advice seems to be somewhat in contradiction to Chrysostom's views in In Mattheum 52 (as discussed above), where Chrysostom opines that the stolen goods should be returned to the people they were stolen from. However, for Chrysostom, it is more likely a case of priority: if the wronged person is known, then restitution should be made to that person; if the wronged person is not known, it is acceptable to make general restitution by almsgiving. Although Chrysostom does not connect Zacchaeus's salvation with his declaration, his use of Luke 19:8b in connection with the eschatological judgement implies that such action might have consequences for eternity.

In homily 18 of the same series, In epistulam primam ad Corinthios, ${ }^{13}$ Chrysostom again notes Luke 19:8b. He posits that not all riches are from God, and likewise not all poverty comes from God. Those riches that do come from God are applied by their owners in a useful way: Chrysostom notes the hospitality of both Job (cf. Job 20:15) and Abraham (e.g. Abraham's treatment of the three men in Genesis 18:1-8). On the other hand, examples of those who acquire wealth through injustice are the rich man in the story of Lazarus (Lk 16:19-31), Ahab and the vineyard (1 Ki 21:1-16), and Gehazi (2 Ki 5:19-5:27). He then connects the narrative of Zacchaeus with a discussion of God's judgement and repentance. God tolerates the latter group of rich people so that there will be sufficient time for them to repent:

But if He immediately punished the wicked rich, Zacchaeus would not have had an appointed time for conversion, so that

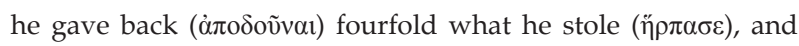
additionally gave away ( $\pi \rho 0 \sigma \theta \varepsilon i \tilde{v} \alpha)$ half of his possessions. (In epistulam primam ad Corinthios 18)

In this case, Chrysostom understood Luke 19:8b to be an example of the repentance of a wicked rich person. The correct response, that is, the repentance that should accompany conversion, is fourfold restitution with almsgiving in addition. Similarly to the use of Luke 19:8b in In Matthaeum 83, Chrysostom has again switched the order of the two actions comprising the declaration of Zacchaeus: rather than almsgiving first and then fourfold restitution, as in Luke 19:8b, Chrysostom refers first to fourfold restitution and then almsgiving. Here, the inversion seems to mean that the fourfold restitution placed Zacchaeus on par, and that giving away half of his possessions is the 'just acquisitions' which are then to be spent 'on the commands of God'; this, then, becomes the sign that Zacchaeus has truly converted.

\section{In epistulam primam ad Thessalonicenses}

In the tenth homily of In epistulam primam ad Thessalonicenses, ${ }^{14}$ concerning 1 Thessalonians 5:12-18, Chrysostom again refers to Luke 19:8b. The reference to Zacchaeus is as an example of repentance:

Tell me, if we possess so much ..., but we have not shared it with anyone, or perhaps [shared] just a little, how shall we rid ourselves of dishonest gains ( $\tau$ às $\left.\pi \lambda \varepsilon 0 v \varepsilon \xi \xi_{1} \alpha \varsigma\right)$ ? For whoever wants to rid themself of dishonest gain does not give a small amount of a large sum, but many times more than he has robbed and stops robbing. Listen what Zacchaeus says: 'And everything that I have robbed (ฑ̋ $\pi \alpha \sigma \alpha$ ), I give back fourfold'. (In epistulam primam ad Thessalonicenses 10$)^{15}$

Chrysostom's concern is, as with the examples discussed above, with items unjustly gained. However, the context here is more than just dishonest gain as such - making manifold restitution serves to dispel greed. As with the reference to Luke 19:8b in In Matthaeum 83 and In epistulam primam ad Thessalonicenses 18, Chrysostom's concern is with the restitution that should be made to someone wronged. Here, the focus is even more on this repayment for wrongdoing, as Chrysostom does not even mention almsgiving.

\section{In loannem}

Chrysostom refers to Luke 19:8b in his In Ioannem twice. The first of these two references is in homily $73,{ }^{16}$ which is on John 13:36-14:7.

Chrysostom connects the element of 'seeing' in John 14:7

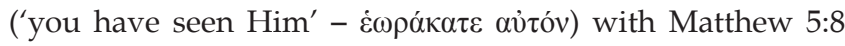
('blessed are those pure in heart, because they will see God'). Chrysostom then explains how one can 'wipe off the

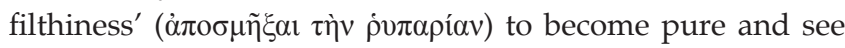
God - in the context, it is clear that this 'filthiness' is brought on by the act of stealing. First, he quotes Proverbs 15:27 (LXX

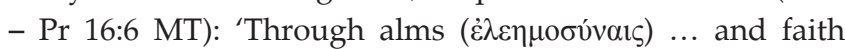

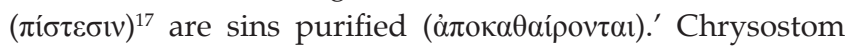
maintains that, of the many cures available, almsgiving is the foremost way to purify ourselves. He insists that one should give away more than what is stolen, and asks: 'What is the use of stripping one person to dress another?'

\footnotetext{
14.The text of In epistulam primam ad Thessalonicenses 10 is available in PG 62:455-462. The reference to Luke $19: 8 \mathrm{~b}$ is on page 460.

15.The translation has been extensively adapted from NPNF1 13:369.

16.The text of In loannem 73 is available in PG 59:395-400. The reference to Luke $19: 8 \mathrm{~b}$ is on p. 398.

17.The translation of $\pi$ íotıs in the plural presents some difficulties. The New English Translation of the Septuagint has opted for 'faithfulness' (cf. Cook 2009:635). Brenton (1851:ad locum) translates as 'faithful dealings'. Another possibility could be 'oaths' (cf. the way the term is used in Thucydides, Historiae 1.35.5). It is, in any case, unsure how Chrysostom would have understood the plural here, and he does not refer to the $\pi \_\tau \varepsilon \tilde{c} \zeta$ again in this context.
} 
Even if we give away everything that we received from others, it is no gain to us. And Zacchaeus pointed this out, when he said that he had propitiated God by giving fourfold of what he had taken away. (In Ioannem 73) $)^{18}$

In this homily, then, Chrysostom states outright that the action of Zacchaeus is 'to propitiate' ( $\dot{\varepsilon} \xi i \lambda \varepsilon o v \tilde{\sigma} \theta \alpha \imath)$ God. For Chrysostom, Luke 19:8b serves as an example that, in propitiation, one should always give more than what was stolen. It is not necessarily Zacchaeus's salvation that is in view, but definitely his standing with God. Once again, it is possessions unjustly acquired that poses a problem.

The next reference to Luke 19:8 in In Ioannem is in homily $88 .{ }^{19}$ In concluding his series of homilies on John, Chrysostom ends his homily by making a final call upon the listener. Even now (i.e. before the judgement), good deeds are rewarded by praise from one's own conscience. Wicked deeds, likewise, are punished by one's conscience. Chrysostom ends by saying that $\sin$ is a heavy thing (on account of conscience); so heavy that even the wicked Ahab had to walk stooping down when his conscience afflicted him. He therefore:

... clothed himself in sackcloth, and shed fountains of tears. If we do this, and grieve as he [i.e. Ahab] did, we shall put off our faults

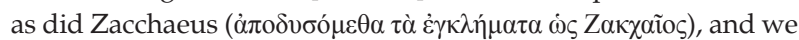
too shall obtain some pardon (

The remainder of the homily then turns in a short general exhortation by Chrysostom to give alms.

Chrysostom here applies Zacchaeus as a type of person who repented, and it is implied that Zacchaeus's declaration was the point of conversion. This is evidenced too by the connection Chrysostom makes between Zacchaeus and almsgiving. Although Chrysostom again does not explicitly say that Zaccahaeus's declaration is a necessary condition for his salvation, he nevertheless does connect Zacchaeus's declaration with guilt and absolution.

\section{Conclusion}

At the start of this article, I identified two ambiguities in the context of Luke 19:8b: the question of how much of his possessions Zacchaeus promised to give away, and the question of why Jesus pronounced 'salvation' for Zacchaeus. Chrysostom is mostly unclear about how much he thought Zacchaeus promised to give away, and not in any of the contexts in which he refers to Luke 19:8b does he call for a total renunciation of wealth. ${ }^{20}$ Rather, Chrysostom advocates

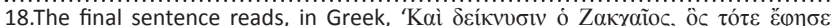

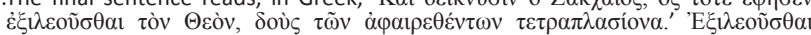
should be taken as the main verb of the indirect discourse introduced by $\check{\varepsilon} \varphi \eta \sigma \varepsilon v$ even though in Luke 19:1-10 Zacchaeus nowhere states that he 'propitiated God'. It appears that Chrysostom is sketching a situation in which Zacchaeus is interpreting his own story, and that Chrysostom makes Zaccheus interpret the events as propitiation by placing these words on his lips.

19.The Greek text of this homily, which concerns John 21:15-25, can be found in PG 59:473-482. The reference to Luke 19:8b is on page 482 .

20.Compare Chrysostom's reservation with regard to giving away all wealth with the context of the reference to Luke 19:8b in Gregory of Nyssa's In diem luminum (Greek text available in Gebhardt 1967:238, lines 20-24) and especially Amphilochius of Iconium's Oratio in Zacchaeum (Greek text available in Datema 1978:171, lines 223-225). Both Gregory and Amphilochius view Zacchaeus as promising to lines $223-225)$. Both Gregory and Amphilochius view Zacchaeus as promising to
give away all his belongings - and appear to apply Luke 19:8b to persuade at least some of their readers to do the same. that there should be righteous rich people (cf. In Matthaeum 83; In epistulam primam ad Corinthios $15 ; 18) .{ }^{21}$

Chrysostom makes a strong link between Zacchaeus's declaration and his salvation, to the point of the latter being contingent on the former in some homilies. ${ }^{22}$ Perhaps this is not surprising, as almsgiving generally forms part of Chrysostom's understanding of the path to salvation (cf. Brändle 2008:138; Leyerle 1994:37; Sitzler 2009:475) but Chrysostom's views on how Zacchaeus's 'salvation' is effected are much more nuanced. Chrysostom views Zacchaeus's declaration as a response to Jesus' prior entering into his house - that is, Jesus' own active seeking and finding the lost - in only one case (In Matthaeum 30). ${ }^{23}$ In the rest of the texts surveyed, Chrysostom rather seems to take the declaration of Zacchaeus as the condition upon which Jesus declares 'salvation'. Once (In Matthaeum 83), Chrysostom even changed around the sequence of the narrative to make this point - contrary to the biblical account, Chrysostom makes Jesus only enter Zacchaeus's house after Zacchaeus made his declaration. However, an even more important theme than the causal link between almsgiving and salvation for which Chrysostom employs Luke 19:8b is that of adequate compensation for people who have been wronged. In almost all of the texts surveyed (with the notable exceptions of In Matthaeum 30 and In Ioannem 88), Chrysostom stresses Zacchaeus's manifold restitution of stolen property rather than his simple act of almsgiving. In two cases (In Matthaeum 83; In epistulam primam ad Corinthios 18), he switches the two elements of Zacchaeus's declaration (almsgiving and restitution) around in order to emphasise restitution. It is clear that Chrysostom did not shy away from changing details of the biblical text to get his point across. In a number of other cases (e.g. De beato Philogonio 4; De Lazaro 2.3; In Ioannem 73), he only refers to restitution, and not almsgiving. Chrysostom connects the almsgiving of Luke 19:8b mainly as part of the restitution, as something that should be given in addition to someone wronged. His primary use of Luke 19:8b is to illustrate the redress of specific unjust acts, whilst almsgiving addresses injustice only in a general way. Chrysostom's main concern is best illustrated by the use of Luke 19:8b in In epistulam primam ad Corinthios 15, where Zacchaeus is presented to illustrate the restitution of specific unjust acts (i.e. 'with much increase'), but not almsgiving, which is reserved as a 'remedy' for when the specifics of unjust acts are not known.

A final theme that runs throughout Chrysostom's reception of Luke $19: 8 \mathrm{~b}$ is that of propitiation. Chrysostom uses

21. A similar theme, connected with a reference to Luke 19:8b, can be found in Clement of Alexandria's Quis dives salvetur 13.5-6 (Greek text available in Früchtel, Stählin \& Treu 1970:168).

22.Perhaps the identification of the link between salvation and Zacchaeus's declaration is the reason why Luke 19:8b is often found at the end of Chrysostom's declaration is the reason why Luke 19:8b is often found at the end of Chrysostom's notoriously 'diverges into moral exhortations with regard to wealth and poverty' notoriously 'diverges into moral exhortations with regard to wealth and poverty' (De Wet 2010:83; cf. Brandle 2008:132) at the end of his sermons. For a general
discussion of how and why Chrysostom makes use of the rich and poor in his discussion of how and why Chrysosto
homilies, see De Wet (2010:84-89).

23.Compare Gregory of Nazianzus (Orationes 39.9 - Greek text in Moreschini \& Gallay 1990:166), who patently understands the moment of conversion as happening on the sycamore tree (Lk 19:4-5) and Zacchaeus's declaration merely happening on the sycamore tree (Lk 19:4-5) and Zacchaeus's declaration merely 271 (PG 31:1269) and Amphilochius of Iconium's Oratio in Zacchaeum (Greek text 271 (PG 31:1269) and Amphilochius of Iconium's
available in Datema 1978:171, lines 223-225). 
Luke 19:8b to illustrate how that which was once used in an unjust way can now restore a person's relationship with God (cf. especially De beato Philogonio 4; De Lazaro 2.3; In Ioannem 73). Although propitiation is not exactly the same as acquiring 'salvation', it would appear that Chrysostom intricately links the two by using a 'salvation' story (Lk 19:1-10, especially 19:8b) to show how one can propitiate God. By incorporating Luke 19:8b into his homilies, Chrysostom the pastor sought to reconcile (Christian) wrongdoers with God.

\section{Acknowledgements Competing interests}

The author declares that he has no financial or personal relationship(s) that may have inappropriately influenced him in writing this article.

\section{References}

Brändle, R., 2008, 'This sweetest passage: Matthew 25:31-46 and assistance to the poor in the homilies of John Chrysostom', in S.R. Holman (ed.), Wealth and poverty in early church and society, pp. 127-139, Baker Academic, Grand Rapids. (Holy Cross Studies in Patristic Theology and History).

Brenton, L.C.L., 1851, The Septuaginta with Apocrypha, Samuel Bagster \& Sons, London.

Brown, P., 2012, Through the eye of a needle: Wealth, the fall of Rome, and the making of Christianity in the West, 350-550 AD, Princeton University Press, Princeton.

Cardman, F., 2008, 'Poverty and wealth as theater: John Chrysostom's homilies on Lazarus and the rich man', in S.R. Holman (ed.), Wealth and poverty in early church and society, pp. 159-175, Baker Academic, Grand Rapids. (Holy Cross Studies in Patristic Theology and History).
Cook, J., 2009, 'Proverbs', in A. Pietersma \& B.G. Wright (eds.), A new English translation of the Septuagint, 2nd edn., pp. 621-647, Oxford University Press, New York.

Datema, C. (ed.), 1978, Amphilochii Iconiensis opera, Brepols, Turnhout. (Corpus Christianorum - Series Graeca).

De Wet, C.L., 2010, 'Vilification of the rich in John Chrysostom's homily 40 On First Corinthians', Acta Patristica et Byzantina 20(1), 82-94.

Früchtel, L., Stählin, O. \& Treu, U. (eds.), 1970, Clemens Alexandrinus, 2nd edn., Akademie Verlag, Berlin. (Die griechischen christlichen Schriftsteller, 3 ).

Gebhardt, E. (ed.), 1967, Gregorii Nysseni opera, Brill, Leiden.

Leyerle, B., 1994, 'John Chrysostom on almsgiving and the use of money', Harvard Theological Review 87(1), 29-47. http://dx.doi.org/10.1017/S001781600003162X

Moreschini, C. \& Gallay, P. (eds.), 1990, Gregory of Nazianzus. Discours 38-41, transl. C. Moreschini, Les Éditions du Cerf, Paris. (Sources Chrétiennes).

O'Toole, R.F., 1991, 'The literary form of Luke 19:1-10', Journal of Biblical Literature 110(1), 107-116. http://dx.doi.org/10.2307/3267153

Ravens, D.a.S., 1991, 'Zacchaeus: The final part of a Lucan triptych?', Journal for the Study of the New Testament 41, 19-32. http://dx.do org/10.1177/0142064X9101304102

Rohrbaugh, R.L., 2007, 'Zaccheus: Defender of the honor of Jesus', in R.B. Coote \& N.K. Gottwald (eds.), To break every yoke: Essays in honor of Marvin L. Chaney, pp. 279-291, Sheffield Phoenix Press, Sheffield.

Sitzler, S., 2009, 'Identity: The indigent and the wealthy in the homilies of John Chrysostom', Vigiliae Christianae 63, 468-479. http://dx.doi. org/10.1163/157007209X413821

Sternberg, M., 1985, The poetics of biblical narrative: Ideological literature and the drama of reading, Indiana University Press, Bloomington.

Tannehill, R.C., 1986, The narrative unity of Luke-Acts: A literary interpretation, 2 vols., Fortress Press, Philadelphia. (Foundations and Facets).

Tannehill, R.C., 1994, 'The story of Zacchaeus as rhetoric: Luke 19:1-10', Semeia 64 201-211.

White, R.C., 1979, 'A good word for Zacchaeus? Exegetical comment on Luke 19:1-10', Lexington Theological Quarterly 14(4), 89-96. 